\title{
Hubungan Kecemasan dan Kejadian Pre Eklamsia di RSUD dr. R. Goeteng Tarunadibrata Purbalingga
}

\author{
Alfi Noviyana ${ }^{1}$, Purwati $^{2}$ \\ Email: alfinovi13@gmail.com \\ Kebidanan D III FIKES, Universitas Muhammadiyah Purwokerto \\ J1. Letjen Soepardjo Roestam Km 7 Purwokerto 53181 \\ Telp/Fax (0281) 6844252
}

\begin{abstract}
Abstrak
Kondisi dimana masa kehamilan dapat meningkatkan kecemasan pada seaorang wanita yang dapat berdampak negatif bagi ibu hamil sendiri maupun bagi janinnya. Anxiety (kecemasan) merupakan salah satu faktor resiko dari kejadian preeklamsi pada ibu hamil Preeklamsi masih menjadi tiga besar penyebab kematian ibu dalam bidang obstetri di Indonesia. Tujuan dari penelitian ini mengetahui dan menganalisis hubungan kecemasan dengan kejadian preeklamsia di RSUD dr.R.Goeteng Tarunadibrata Purbalingga. Penelitian ini adalah penelitian kuanatitatif, dengan desain case control, teknik pengambilan sampel dengan pendekatan acidental sampling. Pengumpulan data menggunakan kuesioner baku dari hamilton. Analisis dalam penelitian kuantitatif menggunakan uji $X^{2}$ (chi square) Hasil penelitian ini bahwa tidak ada hubungan secara statistik antara kecemasan dan kejadian preeklamsi dengan nilai $\rho=0.732$ namun secara klinis didapatkan bahwa ibu dengan kecemasan mempunyai resiko 1, 26 kali lebih tinggi mengalami pre eklamsi (nilai $\mathrm{OR}=1.26$ ). Adapun beberapa variabel luar dalam penelitian ini yang secara teori menjadi faktor predisposisi terjadinya pre eklamsi diantaranya usia, riwayat preeklamsi atau hipertensi sebelumnya, riwayat keturunan, riwayat akseptor KB hormonal berhubungan dengan pre eklamsi.
\end{abstract}

Kata Kunci : Kecemasan, Preeklamsia .

\begin{abstract}
The conditions of pregnancy can increase anxiety in women, therefore it can cause a negative impact on pregnant women themselves and on their fetuses. Anxiety is one of the risk factors of the incidence of pre-eclampsia in pregnant women. Pre-eclampsia is still the top three causes of maternal death in the field of obstetrics in Indonesia. The purpose of this study is to know and analyze the relationship of anxiety with the incidence of pre-eclampsia in RSUD Dr. R. Goeteng Tarunadibrata Purbalingga. This research is a quantitative study, with case control design, sampling technique with an accidental sampling approach. Data collection using a standard questionnaire from Hamilton. Analysis in quantitative studies using the X2 test (chi square) The results of this study that there is no statistical relationship between anxiety and the incidence of pre-eclampsia with a value of $\rho=0.732$ but clinically found that mothers with anxiety have a risk of 1, 26 times higher experience pre-eclampsia ( value of OR =1.26). As for some external variables in this study that theoretically become a predisposing factor for pre-eclampsia including age, previous history of pre-eclampsia or hypertension, hereditary history, history of hormonal family planning acceptors related to pre-eclampsia.
\end{abstract}

Keywords: Anxiety, Pre-eclampsia.

\section{Pendahuluan}

Perubahan status yang
terjadi pada wanita dari masa
sebelum mempunyai anak hingga
janin yang berada dalam kandungan
lahir memerlukan adaptasi dan
persiapan fisik maupun psikologis.
Salah satu bentuk adaptasi

psikologis ibu hamil adalah kecemasan. Kecemasan merupakan unsur kejiwaan yang menggambarkan perasaan, keadaan emosional yang dimiliki oleh seseorang pada saat menghadapi kenyataan atau kejadian dalam hidupnya. Masa kehamilan dapat 
Jurnal Kebidanan Harapan Ibu Pekalongan

\begin{tabular}{l} 
meningkatkan kecemasan pada \\
seaorang wanita yang dapat \\
berdampak negatif \\
$\begin{array}{l}\text { sendiri magi dirinya } \\
\text { dikandungnya. }\end{array}$ \\
\multicolumn{1}{c}{ Anxiety }
\end{tabular}

merupakan salah satu faktor resiko dari kejadian preeklamsi pada ibu hamil. ${ }^{[2]}$ Pernyataan ini didukung pula dengan beberapa penelitian bahwa ibu dengan gangguan kecemasan berkaitan dengan peningkatan resiko mengalami preeklamsia. Depresi atau kecemasan antenatal meningkatkan ekskresi hormon vasoaktif atau neuroendokrin lainnya yang dapat meningkatkan resiko hipertensi, selain itu juga memicu perubahan pembuluh darah dan peningkatan resistensi arteri uterina dimana hal tersebut akan ditemukan pada kasus preeklamsi. $^{[3],[4]}$

Preeklamsi masih menjadi tiga besar penyebab kematian ibu dalam bidang obstetri. ${ }^{[5]}$ Hipertensi dalam kehamilan (Preeklamsia atau eklamsia) menduduki peringakat kedua sebagai penyebab kematian langsung pada ibu dan mengalami peningkatan setiap tahunnya. Menurut beberapa penelitian kematian ibu karena preeklamsia atau eklamsia disebabkan oleh beberapa faktor resiko diantaranya umur ibu, paritas, jarak kehamilan, kehamilan multi/ ganda, riwayat preeklamsia, riwayat keturunan, riwayat penyakit terdahulu seperti diabetes millitus, hipertensi dan penyakit ginjal serta beberapa faktor lain antara lain status sosial ekonomi, riwayat ANC dan kecemasan. ${ }^{[6]}$

Angka kematian ibu (AKI) di Kabupaten Purbalingga menunjukkan penurunan dari 76,76 per 100.000 kelahiran hidup pada tahun 2017 menjadi 75,05 per 100.000 kelahiran hidup pada tahun 2018, namun penyebab kematian ibu karena preeklamsia masih menjadi kelompok penyebab utama. Data rekap medis di RSUD

Dr. R.Goeteng Tarunadibrata

Purbalingga kasus preeklamasi

pada ibu pada tahun 2018 meningkat sebanyak 330 kasus dan 1 kasus kematian ibu karena Preeklamasi berat. ${ }^{[7],[8]}$

Preeklamsia dan

eklamsia merupakan kumpulan gejala yang dapat timbul pada ibu hamil, bersalin dan dalam masa nifas, dan yang menjadi penyebabnya sampai sekarang belum diketahui (The diseasae of Theories). Sebuah penelitian menjelaskan menyebutkan tidak ada hubungan bermakna antara kecemasan dan Preeklamsi namun ibu hamil dengan kecemasan mempunyai resiko terjadin preeklamsi 6,5 kali lebih besar daripada wanita hamil yang tidak mengalami kecemasan. Pengawasan antenatal sangat bermanfaat bagi ibu. Salah satu uji kemungkinan preeklamsia yang meliputi pemeriksaan tekanan darah atau kenaikkannya, pemeriksaan tinggi fundus uteri, pemerikasaan protein dalam urine sebagai upaya deteksi dini preeklamsi. Pendekatan dari sisi psikologis juga dibutuhkan pada wanita karena kecemasan dapat berdampak buruk utuk ibu dan bayi. Beberapa mekanisme biologi dapat menjelaskan hubungan antara gangguan suasana perasaan dan kcemasan dengan resiko preeklamsia. ${ }^{[9]}$ Dari permasalahan tersebut penulis tertarik untuk melaksanakan penelitian tentang kecemasan dan kejadian pre eklamsia di RSUD Dr.R Goeteng Tarunadibrata Purbalingga.

\section{Metode Penelitian}

Desain penelitian yang digunakan adalah analitik korelatif denngan pendekatan case control. variabel penelitian ini adalah kecemasan dan kejadian preeklamsi. Populasi dan sampel 
Jurnal Kebidanan Harapan Ibu Pekalongan

adalah seluruh pasien ibu bersalin di RSUD Goeteng Taruna dibrata Purbalingga pada bulan januari hingga maret 2019, yang dikumpulkan secara accidental sampling dengan jumlah 17 kelompok kasus yakni ibu bersalin dengan preeklamsi dan 17 responden yang merupakan ibu bersalin fisiologis bukan preeklamsi yang tergabung dalam kelompok kontrol. Diagnosis Preeklamsia berdasarkan data rekap medis dan untuk kecemasan menggunakan kuesioner baku dari hamilton.

\section{Hasil Dan Pembahasan}

Data yang diperoleh dari penelitian ini meliputi Usia, paritas, arak kehamilan, riwayat ANC, Riwayat pr eklamsi atau Hipertensi ibu, Riwayat keturunan dan riwayat KB hormonal. Tabel 1.1 menunjukkan komparabilitas antara kasus dan kontrol menurut karakteristik responden .

Tabel 1.1 Perbandingan antara kelompok kasus dan kontrol berdasarkan karakteristik responden penelitian

\begin{tabular}{|c|c|c|c|c|}
\hline Karakteristik & $\begin{array}{l}\text { Kasus } \\
(\mathrm{n}=17)\end{array}$ & $\%$ & $\begin{array}{c}\text { Kontrol } \\
(\mathrm{n}-17)\end{array}$ & $\%$ \\
\hline \multicolumn{5}{|l|}{ Usia } \\
\hline Resiko Tinggi & 12 & 70 & 3 & 17.6 \\
\hline Resiko rendah & 5 & 30 & 14 & 82.4 \\
\hline \multicolumn{5}{|l|}{ Paritas } \\
\hline Primi & 5 & 30 & 8 & 47 \\
\hline Multi & 12 & 70 & 9 & 53 \\
\hline \multicolumn{5}{|l|}{ Jarak Kehamilan } \\
\hline$\leq 2$ tahun & 5 & 30 & 10 & 58.8 \\
\hline$>2$ tahun & 12 & 70 & 7 & 41.2 \\
\hline \multicolumn{5}{|l|}{ Riwayat ANC } \\
\hline$<4$ kali & 3 & 17.6 & 3 & 17.6 \\
\hline$\geq 4 \mathrm{kali}$ & 14 & 82.4 & 14 & 82.4 \\
\hline \multicolumn{5}{|l|}{ Riwayat Pre Eklamsi } \\
\hline $\mathrm{Ya}$ & 11 & 64.7 & 16 & 94.12 \\
\hline \multicolumn{5}{|l|}{ Tidak } \\
\hline \multicolumn{5}{|l|}{ Riwayat Keturunan } \\
\hline Ada & 8 & 47 & 2 & 11.77 \\
\hline Tidak & 9 & 53 & 15 & 88.23 \\
\hline Riwayat & & & & \\
\hline Hormonal & 12 & 70.59 & 6 & 35.3 \\
\hline Ya & 5 & 29.41 & 11 & 64.7 \\
\hline Tidak & & & & \\
\hline
\end{tabular}

Pada kelompok kasus sebanyak 12 responden (70\%) berada pada kelompok umur resiko tinggi, sedangkan pada kelompok kontrol hanya 3 orang saja (17.6\%) yang berada pada rumur besiko tinggi untuk mengalami pre eklamsi. Sekitar 70\% responden kasus adalah ibu multipara, pada kelompok kontrol 53\% meupakan kelompok multipara. Riwayat Antenatal care lebih sama dengan 4 kali pada kelompok kasus dan kontrol sama yakni $82.4 \%$. Pada kelompok kasus terdapat 35.3\% resonden memiliki riwayat preeklamsi atau hipertensi pada kehamilannya atau pada kehamilan sebelumnya, pada kelompok kontrol hanya 5.88\% (1 orang responden) saja yang mempunyai riwayat tersebut. begitu pula pada riwayat keturunan hipertensi pada kelompok kasus sebayak 47\% dan $11.77 \%$ pada kelompok kontrol. Responden pada kelompok kasus yang mempunyai riwayat akseptor KB hormonal sebayak 12 orang (70.59\%), sedangkan pada kelompol kontrol hanya 35.3\% saja. Analisis bivariat dalam penelitian ini bertujuan menenyukan hubungan antara variabel kecemasan dan variabel kejadian reeklamsia. hasil analisis ini tersaji dalam tabel sebagai berikut :

Tabel 1.2 Hasil analisis hubungan antara Kecemasan degan Kejadian Preeklamsi

\begin{tabular}{|c|c|c|c|c|c|c|c|}
\hline \multirow{2}{*}{\multicolumn{2}{|c|}{ Variabel }} & \multicolumn{2}{|c|}{ Preeklamsi } & \multirow[t]{2}{*}{ OR } & \multirow{2}{*}{$\begin{array}{c}\mathrm{CI} \\
95 \%\end{array}$} & \multirow[t]{2}{*}{$\mathrm{X}^{2}$} & \multirow[t]{2}{*}{$\rho$} \\
\hline & & Ya & tidak & & & & \\
\hline \multirow[b]{2}{*}{ Kecemasan } & Cemas & 9 & 8 & \multirow[t]{2}{*}{1.26} & 0.329 & \multirow[t]{2}{*}{0.118} & \multirow{2}{*}{$\begin{array}{l}0.73 \\
2\end{array}$} \\
\hline & $\begin{array}{l}\text { Tidak } \\
\text { cemas }\end{array}$ & 8 & 9 & & 4.867 & & \\
\hline
\end{tabular}

Hasil analisis bivariat tabel 1.2 menunjukkan $\rho=0.732$, OR 1.26 ( CI 0.329 - 4.867) intepretasinya adalah tidak ada hubungan antara 
Jurnal Kebidanan Harapan Ibu Pekalongan

kecemasan dengan kejadian pre eklamsi. Apabila dianalisis vaiabel luar dengan kejadian preeklamsi, maka variabel luar yang memiliki hubungan dengan kejadian preeklamsia adalah vaiable usia, Riwayat pre eklamsi atau Hipertensi, Riwayat keturunan dan riwayat KB hormonal.

Sebagaimana hasil pada tabel 1.3 berikut :

Tabel 1.3 Analisis bivariat antara variabel luar dengan kejadian preeklamsi

\begin{tabular}{|c|c|c|c|c|}
\hline \multirow[t]{2}{*}{ Variabel } & \multicolumn{2}{|c|}{ Preeklamsi } & \multirow[t]{2}{*}{$p$} & \multirow[t]{2}{*}{ OR } \\
\hline & Ya & Tidak & & \\
\hline $\begin{array}{l}\text { Usia } \\
\text { Resiko Tinggi } \\
\text { Resiko rendah }\end{array}$ & $\begin{array}{c}12 \\
5\end{array}$ & $\begin{array}{c}3 \\
14 \\
\end{array}$ & $0.002 *$ & 11.20 \\
\hline $\begin{array}{l}\text { Paritas } \\
\text { Primi } \\
\text { Multi }\end{array}$ & $\begin{array}{c}5 \\
12 \\
\end{array}$ & $\begin{array}{l}8 \\
9 \\
\end{array}$ & 0.290 & 2.13 \\
\hline $\begin{array}{l}\text { Jarak } \\
\text { Kehamilan } \\
\leq 2 \text { tahun } \\
>2 \text { tahun } \\
\end{array}$ & $\begin{array}{c}5 \\
12\end{array}$ & $\begin{array}{c}10 \\
7\end{array}$ & 0.084 & 3.43 \\
\hline $\begin{array}{l}\text { Riwayat ANC } \\
<4 \text { kali } \\
\geq 4 \text { kali }\end{array}$ & $\begin{array}{c}3 \\
14 \\
\end{array}$ & $\begin{array}{c}3 \\
14 \\
\end{array}$ & 1.000 & 1.00 \\
\hline $\begin{array}{ll}\text { Riwayat Pre } \\
\text { Eklamsi } \\
\text { /Hipertensi } \\
\text { Ya } \\
\text { Tidak }\end{array}$ & $\begin{array}{c}6 \\
11\end{array}$ & $\begin{array}{c}1 \\
16\end{array}$ & $0.034^{*}$ & 8.73 \\
\hline $\begin{array}{l}\text { Riwayat } \\
\text { Keturunan } \\
\text { Ada } \\
\text { Tidak } \\
\end{array}$ & $\begin{array}{l}8 \\
9\end{array}$ & $\begin{array}{c}2 \\
15\end{array}$ & $0.024 *$ & 6.67 \\
\hline $\begin{array}{ll}\text { Riwayat } & \text { KB } \\
\text { Hormonal } & \\
\text { Ya } & \\
\text { Tidak } & \\
\end{array}$ & $\begin{array}{c}12 \\
5\end{array}$ & $\begin{array}{c}6 \\
11\end{array}$ & $0.039^{*}$ & 4.40 \\
\hline \multicolumn{5}{|c|}{$\begin{array}{l}1.3 \text { tersebut menampilkan bahwa } \\
\text { variabel luar yang berhubungan } \\
\text { dengan kejadian pre eklamsi adalah } \\
\text { usia dengan } p<0,005 \text { ( } p=0,002) \\
\text { yang artinya ada hubungan yang } \\
\text { bermakna antara usia denga } \\
\text { kejadian preeklamsi dengan OR } 11 \text {, } \\
20 \text { yang berarti resiko terjadinya } \\
\text { preeklamsi } 11,20 \text { kali lebih tinggi } \\
\text { pada usia resiko tinggi. Dalam } \\
\text { penelitian ini yang dimaksud } \\
\text { dengan usia resiko tinggi adalah } \\
\text { responden dengan usia }>35 \text { tahun } \\
\text { atau }<20 \text { tahun, sedangkan usia }\end{array}$} \\
\hline
\end{tabular}

resiko rendah adalah usia 20-35 tahun.

Selain variabel usia, variabel lainnya yang berhubungan dengan kejadian preeklamsia adalah riwayat preeklmasia atau hipertensi selama kehamilan atau kehamilan yang lalu dengan $P=0,034$ dan nilai OR 8,73 sehingga berarti secara statistik ada hubungan antara riwayat preeklmasia atau hipertensi dengan preeklamsi, resiko terjadinya pre eklamsi 8,73 kali lebih besar pada responden yang mempunyai riwayat preeklmasia atau hipertensi selama kehamilan atau pada kehamilan yang lalu. variabel riwayat keturunan juga berhubungan dengan kejadian preeklamsi dengan nilai $P=0,024$ dan $\mathrm{OR}=6.67$, dimana responden yang mempunyai riwayat keturunan keluarga penderita preeklamsi atau hipertensi mempunyai resiko 6,67 kali mengalami preeklamsia pada kehamilan sekarang. Variabel riwayat KB Hormonal juga mempunyai hubungan yang bermakna secara statistik dengan kejadian preeklmasi dengan nilai $P$ $=0.039$, dengan $\mathrm{OR}=4.40$ yang berarti ibu yang mempunyai riwayat sebagai akseptor kontrasepsi hormonal mempunyai resiko 4,40 kali mengalami preeklamsia dibandingkan dengan yang tidak mempunyai riwayat tersebut.

Perubahan psikologis selama kehamilan menuntut seorang ibu hamil untuk dapat beradaptasi, kecemasan adalah suatu bentuk dari adaptasi psikologis tersebut, namun apabila berlangsung terus menerus maka akan mengakibatkan stress hingga depresi. Ibu hamil yang mengalami kecemasan dapat mengakibatkan tekanan darah meningkat. Pada kecemasan terjadi sekresi adrenalin yang berlebihan sehingga menyebabkan tekanan darah meningkat. ${ }^{[9]}$ 
Jurnal Kebidanan Harapan Ibu Pekalongan

Penyebab pasti dari
preeklamsia belum diketahui,
adapun faktor-faktor penyebab
preeklamsi diantaranya, hamil
pertama kali, kehamilan diusia
remaja atau pada usia lebih dari 40
tahun, riwayat hipertensi kronis
sebelum kehamilan, riwayat
mengalami preeklamsia sebelum
kehamilan, riwayat mengalami
preeklamsi sebelumnya, riwayat
preeklamsi pada ibu atau saudara
peremuan, kegemukan, mengandung lebih dari satu bayi, riwayat kencing manis, kelainan ginjal dan lupus. ${ }^{[10]}$

Sebuah penelitian

mengemukakan bahwa kejadian preeklamsia meningkat 7,84 kali pada ibu yang mengalami kecemasan dibandingkan ibu yang tidak mengalami kecemasan. ${ }^{2}$ Berbeda dengan penelitian tersebut, hasil penelitian ini, tidak ada hubungan bermakna secara statistik antara kecemasan dan kejadian preeklamsi di RSUD Dr. R Goeteng Tarunadibrata Purbalingga, namun dari nilai Odd ratio (OR) sebesar 1,26 yang berarti ibu hamil dengan kecemasan memiliki potensi 1,26 kali mengalami preeklamsia. Hal ini serupa dengan penelitian yeng menjelaskan mekipun secara statistik tidak ada hubungan antara kecemasan dengan preeklamsia tetapi secara klinis didapatkan hasil OR sebesar 6,5 yang berarti wanita hamil dengan kecemasan mempunyai risiko terjadinya preeklamsi 6,5 kali lebih besar daripada wanita hamil yang tidak mengalami kecemasan. ${ }^{[9]}$

Adapun dalam penelitian ini terdapat variabel luar yang bisa dikatakan sebagai variabel perancu karena mamnuhi kreteria yakni nerupakan faktor resiko penyakit yang diteliti, mempunyai hubungan dengan paparan dan bukan merupakan bentuk antara dalam hubungannya dengan paparan dan penyakit.
Beberapa variabel luar peda penelitian ini yang secara statistik berhubungan dengan kejadian preeklamsi, diantaranya faktor usia, Secara teori usia merupakan faktor predisposisi terjadinya preeklamsi, dimana usia diatas 35 tahun mempunyai resiko yang lebih tinggi untuk mengalami kejadian preeklamsi, begitu pula insiden hipertensi meningkat. ${ }^{2}$ Pada penelitian lain yang dilakukan di RSUD Penembahan Senopati Bantul, bahwa ada hubungan yang bermakna antara umur dengan kejadian pre eklamsi, dimana resiko terjadinya preeklamsi 6.061 kali lebih tinggi pada ibu dengan umur $<20$ tahun atau $>35$ tahun dibandingkan dengan ibu dengan usia 20-35 tahun. ${ }^{11}$ Bertambahnya umur berkaitan dengan kondisi preeklamsia dimana terjadi perubahan pada sistem kardiovaskuler yang menyebabkan kondisi patologi pada endotel pembuluh darah. ${ }^{\text {[12] }}$

Penelitian ini sejalan dengan sebuah penelitian yang menunjukkan bahwa hampir seluruh ibu hamil yang mempunyai riwayat preekamsi akan mengalami preeklamsi. ${ }^{[13]}$ Wanita dengan riwayat hipertensi kronis meningkatkan resiko 4 kali lipat menalami preeklamsi berulang, wanita dengan riwayat keluarha hipertensi mamiliki resiko 3 kali lebih terkena preeklamsi dan wanita yang mengalami preeklamsia pada kehamilan pertama beresiko 7 kali lebih besar mengalami preekalmsia pada kehamilan kedua. ${ }^{[11]}$

Resiko terjadinya pre eklamsi meningkat pada ibu yang menggunakan kontrasepsi hormonal. ${ }^{[14]}$ Pada peneitian ini, variabel riwayat kontrasepsi hormonal juga berhubungan dengan kejadian preeklamsi, meningkatkan 4 kali resiko ibu mengalami preeklamsi. Hal ini diperkuat oleh sebuah penelitian bahwa ibu 
Jurnal Kebidanan Harapan Ibu Pekalongan

akseptor KB sebelum hamil memiliki kecenderungan untuk terkena preeklamsia ringan 5,636 kali lebih besar dibandingkan dengan bukan aseptor KB sebelum hamil. Hormon dalam kontrasepsi diatur sedemikian rupa sehingga mendekati kadar hormone dalam tubuh aksepor namun apabila digunakan dalam jangka waktu lama akan menimblkan efek samping lain. Namun ada pula penelitian yang mengemukakan bahwa tidak ada hubungan antara faktor riwayat KB hormonal dengan pre eklamsi, tetapi apabila dilihat dari karakteristiknya, ibu yang mengalami preeklamsi sebanyak 53,6\% merupakan akseptor KB Hormonal. [2],[14],[15]

Penyebab kecemasan pada ibu hamil preeklamsi menjelang persalinan antara lain kecemasan terhadap diri sendiri yang meliputi takut mati, takut berpisah dengan bayi, cemas terhadap kesehatan, cemas terhadap rasa nyeri saat persalinan, kemungkinan komplikasi saat hamil atau bersalin, khawatir tidak segera mendapat pertolongan dan perawatan saat melahirkan. Kecemasan tidak langsung berhubungan dengan kehemilan dan persalinan, seperti : takut suami tidak hadir saat persalinan, takut beban hidup semakin berat dan takut akan tanggung jawab sebagai ibu. kecemasan terhadap anaknya yang meliputi : bayi cacat, bayi mengalami kelainan alat-alat tubuh, bayi mangalami gangguan pertukaran zat dalam tubuh, takut keguguran dan kematian dalam kandungan. ${ }^{[16]}$

\section{Kesimpulan}

Tidak ada hubungan secara statistik antara kecemasan dan kejadian preeklamsi di RSUD Goeteng Tarunadibrata Purbalingga. Variabel luar yang menjadi karakteristik responden dan berhubungan dengan dengan preeklamsi adalah Usia, Riwayat Preeklamsi dan Hipertensi, Riwayat Keturunan dan Riwayat KB Hormonal. Ibu hamil yang memiliki riwayat komplikasi pada kehamilannya memicu timbulnya ketakutan akan kondisi bahaya yang dapat terjadi pada dirinya maupun bayinya, sehingga memicu kecemasan. Dengan kecemasan tersebut dapat meningkatkan tekanan darah ibu karena tubuh akan merespon kecemasan yang ditandai dengan peningkatan adrenal ibu sehingga memicu timbulnya preeklamsia.

Perlu meningkatkan upaya deteksi dini preeklamsi dengan antenatal terpadu dan berkualitas. Upaya pengendalian primer perlu ditingkatkan di tingkat pelayanan dasar tentang sosialisasi hipertensi dalam kehamilan (preeklamsi) pada kelompok umum dan khusus, upaya pengendalian sekunder yang meliputi deteksi dini faktor resiko hipertensi dalam kehamilan (preeklamsi) pada kelompok umum dan kelompok khusus. Dan di tinggkat rumahsakit sebagai fasilitas lanjut dengan pencegahan komplikasi.

\section{Daftar Pustaka}

[1] Kumala Fatma Tiara, 2015. Hubungan Antara Kejadian Preeklamsi dan Resiko Depresi Antenatal di RSI Sunan Kudus . Tesis. Universitas Sebelas Maret Surakarta.

[2] Adi Isworo, M. Hakimi, Trisno Agung. 2012. Hubungan antara kecemasan dengan kejadian preeklampsia di Kabupaten Banyumas Jawa Tengah. Berita Kedokteran Masyarakat,Vol. 28 (1) : 9-19

[3] Qiu Chunfang, et all. 2009. Preeclampsia Risk in Relation to Maternal Mood and Anxiety Disorders Diagnosed Before or 
Jurnal Kebidanan Harapan Ibu Pekalongan

During Pregnancy. American Journal of Hypertension (AJH), Vol 22( 4): 397-402

[4] Kurki, et all. 2010. Depression and anxiety in early pregnancy and risk for preeclampsia. The American college of Obstetricians and Gynecologist, Vol 95(4) : 487-490

[5] Kementrian Kesehatan RI. 2015. Profil Kesehatan Indonesia Tahun 2015. Jakarta : Kementrian Kesehatan RI

[6] Dewi Nadia Nurhasanah, Indriani, 2016, Faktor-faktor yang Berhubungan dengan Kejadian Preeklamsia pda Ibu Hamil di RSUD Penembahan Senopati Bantul, Naskah Publikasi Karya Tulis Ilmiah, Universitas Aisyiyah Yogyakarta

[7] Dinas Kesehatan Kabupaten Purbalingga. 2018. Profil Kesehatan Kabupaten Purbalingga tahun 2018

[8] RSUD dr.R Goeteng Tarunadibrata Purbalingga. 2018. Profil tahun 2018. RSUD dr.R Goeteng Tarunadibrata Purbalingga

[9] Intan Rengganis. 2010. Hubungan Antara Kecemasan dengan preeklamsia. Skripsi Universitas Sebelasa Maret. Surakarta

[10] Aiyeyeh Rukiyah, Lia Yulianti. 2012. Asuhan Kebidanan 4: Patologi, Jakarta : Trans Info Media

[11] Dewi Nadia Nurhasanah, Indriani, 2016, Faktor-faktor yang Berhubungan dengan Kejadian Preeklamsia pda Ibu Hamil di RSUD Penembahan Senopati Bantul, Naskah Publikasi Karya Tulis Ilmiah, Universitas Aisyiyah Yogyakarta

[12] Royston, Amnstrong, 2008, Preventing maternal Death, WHO, Genewa
[13] Firda Amalia Hardianti, Queen Khoirun Nisa Mairo, 2018. Kecemasan, Riwayat Preeklamsia dan kejadian Preeklamsia pada ibu hamil Multigravida. Jurnal Keperawatan Terapan. Vol 4(1) : 21-26

[14] Fajriansi. 2013. Hubungan antara Penggunaan Kontrasepsi Oral dengan Peningkatan Tekanan Darah pada Akseptor KB Aktif di Puskesmas Maningpajo Kecamatan Wajo. Jurnal Stikes Nani Hasanuddin. Vol $3(4): 30-33$

[15] Setiawan, 2016, Hubungan Paritas dan Kontrasepsi enngan Preeklamsia Ringan di Puskesmas Jangir. Jurnal Berkala Epidemiologi, Vol 4(1) : 100-112

[16] Desi Trisani, Rima Hikmawati. 2016. Hubungan Kecemasan Ibu Hamil Terhadap Kejadian Pre Eklamsia di RSUD Majalaya Kabupaten Bandung.Jurnal Ilmiah Bidan. Vol I(3) : 14-18 